特集 3

\title{
大腸癌の原発巣と転移巣における形質発現の \\ 差異と，間質との相互作用に関する検討
}

\begin{tabular}{llllll}
\multicolumn{7}{c}{ 京都大学第 1 外科 } \\
石上 & 俊一 & 有井 & 滋樹 & 原田 & 富嘉 \\
水本 & 雅己 & 森 & 章 & 花木 & 宏治 \\
武田 & 佳久 & 小野寺 & 久 & 今村 & 正之
\end{tabular}

原発巣, 転移巣あわせて74例の大腸癌における, VEGF (vascular endothelial growth factor), MMP (matrix metalloproteinase)-2, -9, MT1-MMP (membrane type matrix metalloproteinase) の発現の違いを, Northern hybridization と免疫組織染色にて検討した，肝転移を有する原発巣での これら分子の遺伝子発現は，肝転移のない原発巣よりいずれも高かったが，肝転移巣における発現は 原発巣より高いとは限らなかった. リンパ節転移を有する原発巣は, リンパ節転移のない原発巣に比 べVEGF の発現が高く,リンパ節転移巣においては, 原発巣に比べVEGF と MMP-9の発現が高かっ た。肝転移巣の免疫染色に扔いては, VEGFやMMP-20発現は, 癌細胞でなく, むしろ隣接する肝細 胞に認められた. 以上の結果は, 癌の形質発現が転移先の缄器の環境要因によって左右されること, そして転移という現象が，癌細胞と間質，あるいは肝細胞や炎症細胞との相互関係によって成立する ことを示唆しているものと考えられた。

Key words : colorectal cancer, vascular endothelial growth factor, matrix metallo-proteinases

\section{はじめに}

癌の浸潤・転移は癌の増殖に始まり, 癌細胞の原発 巣からの離脱, 細胞外マトリックスの分解と組織内移 動, 基底膜の破壊による血管内侵入, 血流による運搬, 血管内皮への接着と血管外脱出, 転移臟器への生着お よび増殖といった具合に多段階を経て成立するものと され，癌細胞とそれを取り巻く間質との相互関係で成 立するものと考えられている"．それ故に，転移という 複雑な現象を単一の因子だけで説明することは適切で なく, 癌を取り巻く周囲環境を無視し，癌細胞だけを 取り上げて論ずることも適切でないと思われる。これ らの過程には，血管新生因子を初めとする増殖因子, 細胞間接着分子，細胞外マトリックス分解醉素など多 くの分子がかかわっていることが推測される. 血管内 皮細胞の特異的な增殖因子である vascular endoth-

*第50回日消外会総会シンポ 2 ・癌細胞と間質との相 互関係からみた転移, 浸潤の諸問題

$<1997$ 年12月 3 日受理 $>$ 別刷請求先：石上 俊一 于520-0046 大津市長等 $1-1-35$ 大津赤十字病院 外科 elial growth factor (VEGF) は，血管新生を介して 癌の增殖進展に関わっているとされ，これまでにも血 管密度や予後との関連を示した数多くの臨床研究がな されている21.一方, matrix metallo-proteinases (MMPs) は, 癌間質や血管基底膜の消化にかかわって いるとされる一群の酵素群で, これらのうち癌間質の 主たる構成成分である type IV collagen 基質とす るものには, MMP-2, MMP-9の 2 種類がある ${ }^{3}$. 最近, 細胞膜貫通領域を有し, 潜在型 MMP-2を特異的に活 性化しうるMMPとして membrane type matrix metallo-proteinase (MT-MMP) が確認された4. MT-MMP は現在までに 4 種類の isoform の存在が 知られているが, 今回の研究では, 大腸癌における発 現が確諗されて抢り，浸潤・転移と深い関係があると されるMT1-MMP を対象とした ${ }^{51}$. 研究の主たる目的 は，大腸癌原発巣抢よび転移栄におけるこれら 4 種類 の分子の発現の違いを検討し, 臨床的な意義や臨床応 用の可能性を探ることにある.

\section{対象と方法}

1. 対象は1994年 4 月より1996年 7 月までの 2 年 4 
か月間に当科にて切除術を施行された大腸癌 74 症例 で，原発巣が66例，肝転移巣15例（同時性 7 例，異時 性 8 例), リンパ節転移巣12例であった。患者年齢は 45 90歳 (平均64.7歳) で, 男女比は1.64：1 であっ た。

2. 手術にて得られた大腸癌の新鮮切除標本から, 癌 部および非癌部を別々に採取し, 直ちに $-80^{\circ} \mathrm{C} て ゙$ 涷結 保存した。癌部, 非癌部それぞれから, 塩化セシウム 超遠心法にて total RNA を抽出し, さらに poly-A $\mathrm{A}^{+}$ RNA を精製した. MT1-MMPに関しては $20 \mu \mathrm{g}$ の total RNA を，VEGF，MMP-2，MMP-9の 3 者に関 しては $5 \mu \mathrm{g}$ の poly- $\mathrm{A}^{+}$RNAを用いて Northern hybridization を施行した。

3. autoradiographyにて得られた画像より,各サン プルにおける各遺伝子の発現量を計測し数値化した. S26 ribosomal protein (S26rp) cDNA を用いて, 各 メンブランを rehybridization し, この遺伝子の発現 量を internal controlにして, 各遺伝子の発現量を補 正した。正常部 $(\mathrm{N})$ に対する腫瘍部 $(\mathrm{T})$ での各遺伝 子の相対発現量 $(\mathrm{T} / \mathrm{N}$ 比) を計算し, 以後の解析に用 いた.

4.さらに原発巣および肝転移巣における各分子の 組織内局在を検討するために, ホルマリン固定パラ フィン包埋切片に対して, ABC 法による免疫組織染色 を施行した. VEGFの染色には, 日本医科大学病理学 教室より供与された抗ヒトVEGFウサギポリクロ ナール抗体を $0.2 \mu \mathrm{g} / \mathrm{ml}$ の濃度で使用し, MT1-MMP に関しては, 金沢大学癌研より供与された抗七ト MT1-MMP マウスモノクロナール抗体（113-5B7）を $0.5 \mu \mathrm{g} / \mathrm{ml}$ の濃度で使用した。 MMP-2および MMP-9 に関しては, 富士薬品工業株式会社より購入したマウ スモノクロナール抗体を，それぞれ $1.0 \mu \mathrm{g} / \mathrm{ml}$ の濃度 で使用した。

5. 統計学的解析には, unpaired t test を用い, p 值 が 0.05 末満のものを有意とした.

\section{結 果}

（1）原発巣扝よび転移巣に打ける遺伝子発現

Northern Hybridization の代表例を Fig. 1 に示 す.VEGFやMT1-MMP の遺伝子発現は, 非癌部で はほとんど認められなかったが, 原発巣や転移巣の癌 部においては, 種々の程度の発現増強が観察された。 MMP-2に関しては, 正常大腸粘膜や正常肝においても 強い発現の認められる事があり,MMP-9に関してはリ ンパ節転移巣での発現増強が特徵的であった. 原発巣,
Fig. 1 Northern hybridization of VEGF and MMPs in human colorectal cancer tissues. Overexpression of VEGF and MMPs mRNA were observed both in primary and metastatic tumors. Autoradiograms were quantified by densitometry, and gene expression in tumor was compared to that in nomal control. LN : Lymph Node, meta : metastasis, S26 rp: S26 ribosomal protein
VEGF
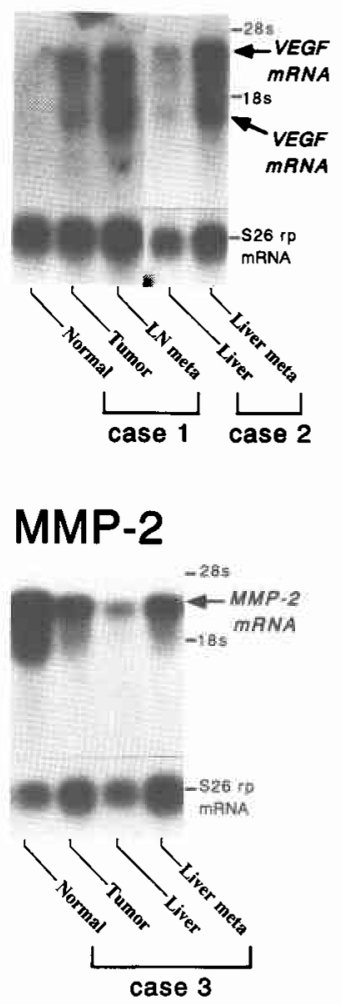

MT1-MMP

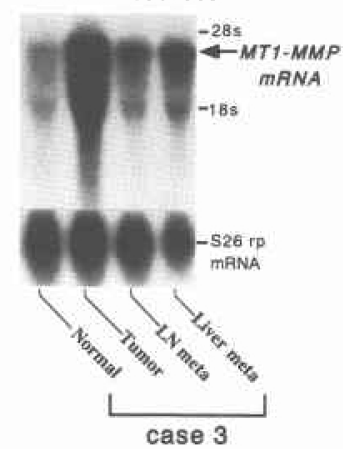

MMP-9

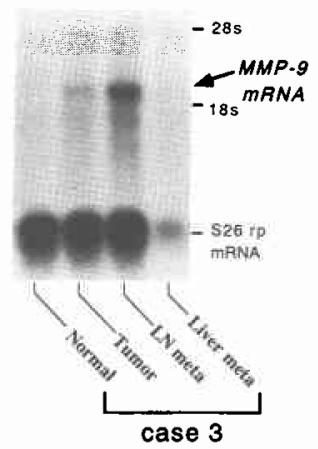

肝転移巣やリンパ節転移巣におけるこれら 4 種類の遺 伝子の発現に,一定の傾向があるか否かを調べるため, 転移を伴わない原発巣, 転移を伴う原発巣, 転移巣の 3 群における $\mathrm{T} / \mathrm{N}$ 比の平均値を比較した。

\section{1. 肝転移と遺伝子発現}

肝転移を伴わない原発巣, 肝転移を伴了原発巣, 肝 転移巣のそれぞれに招ける $\mathrm{T} / \mathrm{N}$ 比の平均土標準偏差 を Table 1 に示す. 肝転移を伴う原発巣での $\mathrm{T} / \mathrm{N}$ 比 の平均値は, VEGF $(\mathrm{p}<0.0001)$, MT1-MMP $(\mathrm{p}=$ 0.002), MMP-2 ( $\mathrm{p}=0.02)$, MMP-9 $(\mathrm{p}=0.0013)$ の いずれに関しても, 肝転移を伴わない原発巣に比べ有 意に高かった。また，いずれの分子に関しても，肝転 
移巣における平均値が，肝転移を有する原発巣のそれ を越えることは無かった.肝転移巣におけるVEGF 遺 伝子の発現は，肝転移を有する原発巣に比べ有意に低 $く(\mathrm{p}=0.004)$, 肝転移巣における MT1-MMP 遺伝子 の発現は, 肝転移の無い原発巣に比べ有意に高かった $(\mathrm{p}=0.005)$.

2.リンパ節転移と遺伝子発現

リンパ節転移を伴わない原発巣, リンパ節転移を伴 う原発巣，リンパ節転移巣のそれぞれにおける $\mathrm{T} / \mathrm{N}$ 比の平均士標準偏差を Table 2 に示す. VEGF に関し てのみ,リンパ節転移を伴う原発巣での発現の平均が, リンパ節転移を伴わない原発巣のそれに比べ有意に高 かった $(\mathrm{p}=0.036)$.リンパ節転移巣での発現の平均值 は, VEGFに関しては転移のない原発巣より有意に高 く $(p=0.033)$, MMP-9に関しては転移を有する原発 巣よりも有意に高かった $(p=0.013)$. 遺伝子発現の程
度を表す T/N 比は，VEGF，MMP-9のいずれに関し ても，原発巣よりリンパ節転移巣の方が高い值を示し た.

（2）原発巣および肝転移巣の免疫組織染色

原発巣におけるVEGF の発現は主として癌細胞に 認められ (Fig. 2A), 発現の程度は病期の進行ととも に増強する傾向が観察された，特に肝転移を有する原 発巣においては, VEGF の産物は癌細胞内にとどまら ず，周囲の間質にも散在性に分布していた，肝転移巣 においては,転移結節の癌細胞に VEGF の発現は認め られず，むしろ結節近傍の肝細胞が染色された（Fig. 2B).

MT1-MMPに関しては，同時に切除された原発巣 (Fig. 2C)，リンパ節転移巣，肝転移巣 (Fig. 2D) の いずれにおいても, 癌細胞が強く染色された。ただし， 原発巣よりもリンパ節転移巣, リンパ節転移巣よりも

Table 1 VEGF and MMPs mRNA expression in primary tumor and metastatic liver tumor

\begin{tabular}{|c|c|c|c|}
\hline & \multicolumn{2}{|c|}{ Primary tumor } & \multirow{2}{*}{$\begin{array}{c}\text { Metastatic } \\
\text { Liver Tumor }\end{array}$} \\
\hline & Liver metastasis $(-)$ & Liver metastasis $(+)$ & \\
\hline VEGF & $2.57 \pm 1.98$ & $8.39 \pm 7.48^{\mathrm{a}}$ & $1.92 \pm 2.03^{\circ}$ \\
\hline MT1-MMP & $2.93 \pm 3.00$ & $13.95 \pm 24.40^{\mathrm{a}}$ & $5.87 \pm 4.57^{\mathrm{a}}$ \\
\hline MMP-2 & $1.33 \pm 1.65$ & $3.12 \pm 3.85^{\mathrm{a}}$ & $1.25 \pm 0.84$ \\
\hline MMP-9 & $1.02 \pm 0.89$ & $5.55 \pm 9.32^{\mathrm{a}}$ & $\begin{array}{r}4.92 \pm 14.05 \\
(15)\end{array}$ \\
\hline
\end{tabular}

${ }^{a}$ The expression is significantly higher than the cases without liver metastasis.

${ }^{\mathrm{b}}$ The expression is significantly lower than the cases with liver metastasis.

Table 2 VEGF and MMPs mRNA expression in primary tumor and metastatic lymph node

\begin{tabular}{|c|c|c|c|}
\hline & \multicolumn{2}{|c|}{ Primary tumor } & \multirow{2}{*}{$\begin{array}{l}\text { Metastatic } \\
\text { Lymph node }\end{array}$} \\
\hline & $\begin{array}{l}\text { Lynph node } \\
\text { metastasis }(-)\end{array}$ & $\begin{array}{l}\text { Lymph node } \\
\text { metastasis }(+)\end{array}$ & \\
\hline VEGF & $2.61 \pm 3.75$ & $5.18 \pm 5.22^{\mathrm{a}}$ & $\begin{array}{r}12.92 \pm 23.83^{\mathrm{a}} \\
(9)\end{array}$ \\
\hline MT1-MMP & $\begin{array}{r}3.08 \pm 3.47 \\
(28)\end{array}$ & $7.17 \pm 16.11$ & $4.66 \pm 6.92$ \\
\hline MMP-2 & $1.58 \pm 2.15$ & $1.83 \pm 2.58$ & $1.14 \pm 1.90$ \\
\hline MMP-9 & $2.13 \pm 6.67$ & $2.07 \pm 2.91$ & $\begin{array}{r}7.57 \pm 11.75^{\mathrm{b}} \\
\text { (11) }\end{array}$ \\
\hline
\end{tabular}

aThe expression is significantly higher than the cases without lymph node metastasis.

${ }^{\text {'T }}$ The expression is significantly lower than the cases with lymph node metastasis. 
Fig. 2 Immunohistochemical staining for VEGF and MMPs in colorectal cancer tissues. (A) VEGF expression in primary tumor with liver metastasis, $\times 1,000$ (B) VEGF in metastatic liver tumor, $\times 400$ (C) MT1-MMP in primary tumor with liver metastasis, $\times 200$ (D) MT1MMP in metastatic liver tumor, $\times 200$ (E) MMP. 2 in primary tumor with liver metastasis, $\times 400$ (F) MMP-2 in metastatic liver tumor, $\times 200(\mathrm{G})$ MMP-9 in primary tumor with liver metastasis, $\times 400(\mathrm{H})$ MMP-9 in metastatic liver tumor, $\times 400$. Ca: cancer cells, $\mathrm{L}:$ hepatocytes, fib : fibroblasts

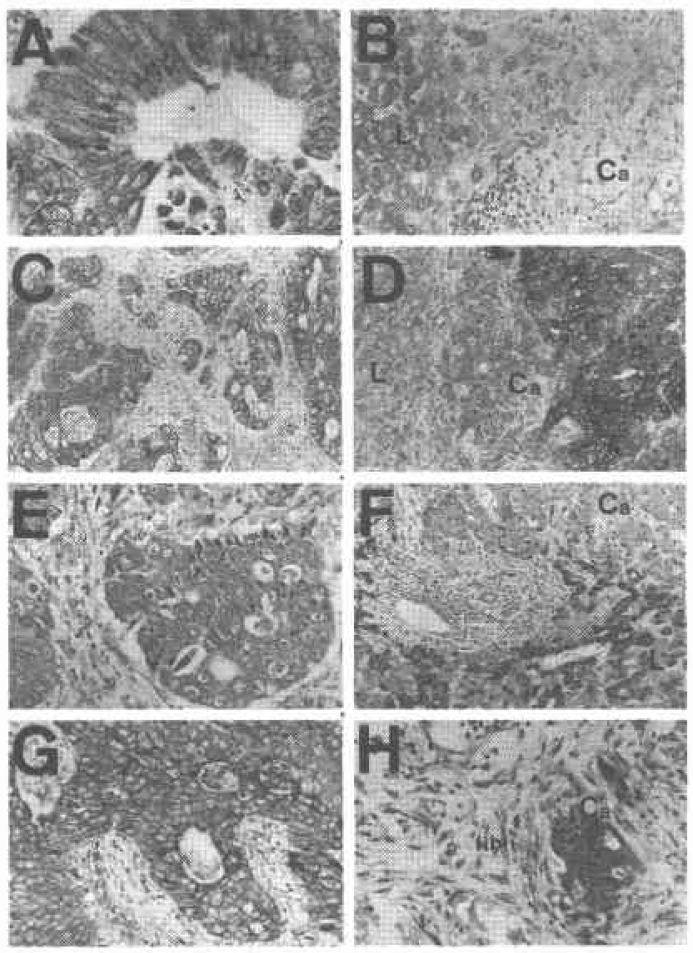

肝転移巣という具合に, 常に癌の浸潤先進部において, その発現が高くなる傾向が観察された。

原発巣での MMP-2の主たる発現細胞は, 間質の線 維芽細胞であったが, 肝転移を伴う原発巣においては 癌細胞にも染色性が認められた（Fig. 2E)。しかしな がら, VEGF の場合と同様, 肝転移巣では癌細胞はほ とんど染色されず，むしろ転移結節近傍に分布する肝 細胞がこの蛋白を強く発現していた（Fig. 2F).

原発巣におけるMMP-9の発現は, 癌細胞以外にも, 線維芽細胞, 好中球, $\mathrm{M \phi}$, 血管内皮細胞など, 多種類 の細胞に㧍いて観察された（Fig. 2G）。間質成分に之
しい小さな肝転移結節においては，好中球， $\mathrm{M} \phi$ と いつた間葉系の細胞が主にこの蛋白を発現しているの に対して, 間質成分の豊富な巨大結節においては, 線 維芽細胞や癌細胞にもMMP-9の発現が観察された (Fig. 2H).

\section{考察}

癌の浸潤・転移は多くの過程を経て成立するものと 考えられており，各過程には多くの分子が関与してい ると推測されている.VEGF は，もともと血管の透過 性を穴進させる物質として同定されたが, 強力な血管 新生作用を有することから，腫瘍の増殖に不可欠な分 子として認識されるようになった。一方, MMP-2, -9 は血管基底膜の構成成分であるコラーゲンの分解能力 を有することから，浸潤・転移において重要な分子で あると考えられるようになった、VEGFやMMPs の 発現は決して癌に特有なものではなく, 正常組織の修 復過程においても観察されることが報告されている。 しかしながら, 正常組織でのこれらの分子の発現がさ ほど高くないこと, 癌組織でこれら分子の過剰発現が しばしば観察されることから，正常の個体が有するこ れらの機構を, 癌が自らの増殖や浸潤・転移に利用し ているのだと考えられるようになった。我々は以前よ り, 病期の進行した大腸癌症例ほど, 原発巣でのこれ ら浸潤・転移関連分子の遺伝子発現が高いことを報告 してきたが，今回は特に転移という現象に着目し，転 移の有無別に見た原発栄でのこれら分子の発現の違い や, 原発巣と転移巣での発現の違いについて検討した。 原発巣での VEGF 遺伝子の発現は, その腫瘍がリン パ節転移や肝転移を伴う場合に有意に高く，転移リン パ節での発現はこれよりもさらに高くなる傾向を示し た。しかしながら，肝転移巣に招ける発現は，予想に 反して肝転移を有する原発巣より低く，これは免疫染 色の結果に沿うものであった。肝転移巣では, VEGF 蛋白の発現はむしろ転移結節に隣接した肝細胞に認め られ，転移結節そのものは染色されなかった。すなわ ち, 癌が増殖や浸潤を繰り返しながらリンパ節転移巣 を形成する一連の過程において, VEGF が重要な役割 を演じている事はほほ間違いないと思われる。しかし ながら，いったん肝転移が形成されれば，転移結節に おける癌の増殖は, 肝細胞が発現するVEGF に依存す るようになるのかもしれない.ここで問題となるのは, 肝細胞にVEGF の発現を誘導する物質が何であるか ということであり，この分子機構を解明することが今 後の我々の研究課題である.目下のところ, 細胞間接 
着分子や種々のサイトカインをその候補と考え, 研究 を進めているところである.

一方, MT1-MMP に関しては, 原発巣はもちろんの こと,リンパ節転移巣や肝転移巣に扔いても強い発現 が観察された。原発巣と, 同時に切除しえた転移巣で の染色性を比較したところ, MT1-MMP の発現は浸 潤先進部と考えられる部位において最も強く, 特に肝 転移結節の癌細胞での発現は，15例全例に扔いて陽性 であった，転移を有する原発巣での MT1-MMP の遺 伝子発現の平均値は, 転移巣における平均よりも高い 值を示したが，これは転移巣の検討症例数が少ないこ とによるものと考えられた.MT1-MMPの発現を考 える際に，MMP.2との関係を無視することはできな い. MT1-MMP は，潜在型 MMP-2を活性型に変換す ることが知られているが，同時に細胞膜表面への MMP-2の結合を誘導するとの報告もある ${ }^{6}$. 肝転移巣 の免疫組織学的検討によれば, MMP-2の発現は VEGF の場合々同様，転移結節そのものよりもむしろ 近傍の肝細胞に認められた. 肝細胞にMMP-2の発現 が誘導される機序に関しては不明だが, MT1-MMP の関与が推測される。すなわち, 肝転移巣に発現した MT1-MMP の作用により，隣接する肝細胞膜表面に MMP-2の発現が誘導され,さらに転移結節近傍に分布 するMMP-2が, MT1-MMPの働きにより活性化さ れ, 転移巣の発育進展を容易にしているのではないだ ろうか.

免疫染色で確認されたMMP-9発現陽性細胞は, 原 発巣においても肝転移巣においても多彩であった。転 移を伴わない原発巣や小さな肝転移結節のように, 間 質の乏しい症例に扔いては, 好中球や $M \phi$ といった炎 症性の細胞が主にこの蛋白を発現していたが, 進行し た原発巣や巨大な肝転移結節のように間質が発達した 症例においては, これら炎症細胞以外にも線維芽細胞 や癌細胞が強く染色された.

また, MMP-9の Northern hybridization では,リ ンパ節転移巣における発現立進が特徴的であったが, 免疫染色では転移した癌細胞および濾胞内のリンパ球 にMMP-9の強い発現を認めた。転移のないリンパ節 の染色を施行していないため明確なことは言えない が, リンパ節内に転移巣が形成されると、リンパ系の 細胞に MMP-9の発現が誘導されるのかもしれない.

これら分子発現の意義をまとめると以下のようにな る.リンパ節転移に関しては, VEGF と MMP-9の 2 者 の発現が重要である。すなわち，原発栄の解析でこれ
ら分子の遺伝子発現が高かった症例は，リンパ節再発 を来卞可能性が高いと考えられる。一方, 肝転移巣に おけるこれら分子の発現は，それぞれの転移結節に よって異なるようである。すなわち，病巣が小さく間 質の発育が不十分な間は, 癌細胞に発現している MT1-MMP が, 肝細胞膜表面に発現している MMP-2 を活性化し，また一方では好中球や M申といった炎症 性の細胞が MMP-9を産生して, 間質の再構築や転移 結節の増大にかかわっていると考えられる．間質が豊 富となり線維芽細胞が増生してくると, 線維芽細胞が MMP-2や-9を大量に産生するようになり，このころに は癌細胞もこれらを発現するようになるのであろう。

これらの分子を実際の治療に応用する場合には，2 通りの方法が考えられる. 1 つは, 臨床診断への応用 である. 例えぱ, 原発巣切除後に補助療法が必要かど うかを判断する基準として利用できる．手術時に肝転 移が明らかでなかったにもかかわらず，原発巣でこれ ら分子が高発現であった症例は，すでに転移巣が形成 されているか, あるいは将来, 肝転移を来す可能性が 高いであろうと予測できる。 また，リンパ節転移巣に おけるVEGFやMMP-9の遺伝子発現を検討するこ とで, micro metastasis の存在を明らかにすることが 出来るかもしれない，2つ月は，治療への応用である. 転移にかかわる主たる分子がわかれば，これに対する 阻害郕や中和抗体を用いたり，あるいは癌細胞や線維 芽細胞に，その分子に対するアンチセンスを導入し， 原因分子の発現を抑制することができる。しかし実際 には, 発現している浸潤・転移関連分子は単一でなく, しかも時事刻々と変化している可能性が高いので，そ の時々で使用する薬刻を変える必要があるかもしれな い.

以上のように，原発巣と転移巣における VEGF， MMPs の発現動態は必ずしも同一ではなかった.この 事実は, 癌の形質発現が転移先の藏器の環境要因に よって左右されること，そして転移という現象が，癌 細胞とそれを取り巻く間質との相互関係, あるいは癌 細胞と肝細胞や炎症細胞との相互関係によって成立す ることを示唆しているものと考えられた．現在までの ところ, 術後の転移・再発を早期に察知する方法はな い。これら浸潤・転移関連分子の発現を詳細に検討す れば，リンパ節転移や肝転移を繰り返すような症例の 選別や，新たなる治療の開発に役立てることが出来る ようになるかもしれない. 


\section{文 献}

1) Liotta LA, Steeg PS, Stetler-Stevenson WG: Cancer metastasis and angiogenesis: an imbalance of positive and negative regulation. Cell 64:327-336, 1991

2) Takahashi $Y$, Kitadai $Y$, Bucana $C D$ et al: Expression of Vascular Endothelial Growth Factor and its receptors, KDR, correlates with vascularity, metastasis, and proliferation of human colon cancer. Cancer Res 55:39643968,1995

3) Sato H, Kida Y, Mai M et al: Expression of genes encoding type IV collagen-degrading metalloproteinases and tissue inhibitors of metalloproteinases in various human tumor cells. Oncogene $7: 77-83,1992$

4) Sato $H$, Takino $T$, Okada $Y$ et al: A matrix metalloproteinase expressed on the surface of invasive tumor cells. Nature $370: 61-65,1994$

5) Ueno $H, N a k a m u r a ~ H$, Inoue $M$ et al : Expression and tissue localization of membrane-types 1,2 , and 3 matrix metalloproteinases in human invasive breast carcinomas. Cancer Res 57 : 2055-2060, 1997

6) Sato H, Takino $T$, Kinoshita $T$ et al: Cell surface binding and activation of gelatinase $\mathrm{A}$ induced by expression of membrane-type-1. matrix metalloproteinase (MT1-MMP). FEBS Lett 385 : 238-240, 1996

\title{
The Different Expression of Metastasis Related Molecules in the Primary and Metastatic Tumors of Human Colorectal Cancer - Interrelationship between Cancer Cells and Stromal Tissues-
}

\author{
Shun-ichi Ishigami, Shigeki Arii, Tomika Harada, Masaki Mizumoto, \\ Akira Mori, Kouji Hanaki, Yoshihisa Takeda, \\ Hisashi Onodera and Masayuki Imamura \\ First Department of Surgery, Faculty of Medicine, Kyoto University
}

The expression of vascular endothelial growth factor (VEFG), matrix metalloproteinase (MMP)-2, -9 , and membrane type matrix metalloproteinase (MT1-MMP) in surgical specimens of 74 colorectal cancer patients were evaluated by Northern hybridization and immunohistochemistry, and the difference between primary tumors and metastatic tumors was investigated. The expression of mRNA of these 4 molecules in the primary tumors with liver metastasis tended to be higher in those without liver metastasis. But gene expression in metastatic tumors of the liver was not always higher than in the primary tumors. The VEGF gene expression in the primary tumors with lymph node metastasis tended to be higher than in those without lymph node metastasis. Both VEGF and MMP-9 mRNA expression in the metastatic lymph nodes tended to be higher than in the primary tumors. Immunohistochemical staining for metastatic liver tumors showed that the expression of VEFG or MMP-2 protein was not observed in the cancer cells but in hepatocytes neighboring the metastatic nodules. These results suggest that the expression of VEGF or MMPs may be changed by the circumstances of target organs, and that cancer metastasis may be brough into being through an interrelationship among cancer, cells, stromal cells and hepatocytes.

Reprint requests: Shun-ichi Ishigami Otsu Red Cross Hospital 1-1-35 Nagara, Otss city, 520-0046, JAPAN 